\title{
TRADUÇÃO DO PREFÁCIO DE ÉTIENNE GILSON À EDIÇÃO EM LÍNGUA INGLESA DE 1964 DE LA POÉTIQUE DE L'ESPACE, DE GASTON BACHELARD
}

BACHELARD, Gaston. [Poetique de l'espace / 1958] The poetics of space. Foreword by Étienne Gilson. Massachusetts: Beacon Press, 1964.

Gustavo Bertoche*

Um homem incomum, com uma carreira incomum e uma mente ainda mais incomum, Gaston Bachelard era tão modesto que provavelmente poucos de seus contemporâneos se lembrarão dele quando jovem, quando lentamente abria o seu caminho, desde os trabalhos subalternos na administração pública até a cadeira de filosofia na Sorbonne. Quem será lembrado é o último Bachelard, o adorável patriarca, com um acentuado sotaque rural, amado pelos estudantes - por quem generosamente se dedicava - mas conhecido pelos seus vizinhos como um velho homem que, no mercado, gostava de escolher ele mesmo o peixe ou o pedaço de carne.

Eu gostaria de ressaltar como a sua origem rural e a sua familiaridade com as coisas da terra afetaram a sua vida intelectual e influenciaram o curso das suas reflexões filosóficas. Graças aos seus corajosos esforços, Bachelard finalmente conseguiu adquirir uma educação universitária, obteve todos os graus possíveis e terminou como professor universitário; além disso, diferentemente da maioria de nós (pelo menos na França), nunca se deixou moldar pela forma de pensar tradicional que as universidades inevitavelmente impõem aos seus alunos. A sua superioridade intelectual era tamanha que ele jamais falhou em seus projetos acadêmicos. Todos o amávamos, o admirávamos e também o invejávamos um pouco, porque sentíamos que a sua mente era livre, indiferente a todas as convenções — tanto em relação aos problemas com que desejava lidar, quanto em relação ao modo como lidava com eles.

O que o leitor descobrirá neste volume (BACHELARD, 1964) assinala o último estágio da sua carreira filosófica. As primeiras páginas da Introdução sugerem que ele mesmo sentia, então, a necessidade de explicar ao seu público as razões por trás dos seus interesses estéticos recentes.

Quando era um jovem filósofo, Bachelard devotara sua atenção aos problemas

\footnotetext{
* Doutor em Filosofia. Professor da Universidade Iguaçu - UNIG. E-mail: gusbertoche@gmail.com.
} 
relacionados à natureza do conhecimento científico, especialmente na física. Foi como especialista na filosofia da ciência que inicialmente se tornara conhecido e estabelecera a sua reputação. Treze volumes, se não me engano, nos quais a competência científica andou lado a lado com agudeza filosófica, justificaram amplamente a sua reputação. Entre esses volumes, pelo menos um título deve ser aqui mencionado: L'Expérience de l'Espace dans la Physique Contemporaine (1937). O que eu quero deixar claro é que toda a sua carreira como professor universitário foi fundada em sua crítica filosófica do conhecimento científico e na sua concepção de um tipo livre de racionalismo - bastante diferente do modo de pensar abstrato que a palavra geralmente designa - , completamente assentado na arte de usar a razão como um instrumento para se aproximar, progressivamente, à realidade concreta.

Nessa época, seria fácil prever o futuro da carreira de Bachelard. Especializando-se na filosofia da ciência, provavelmente haveria de escrever mais uma dezena de livros sobre o assunto. Mas não era para ser assim. Bachelard deu o disparo de advertência quando, inesperadamente, publicou um livro curiosamente intitulado La Psychoanalyse du Feu (1938). Lembro da minha primeira reação a ele: “o que será que vão pensar?” Mas quem vão pensar? Bem, nós, todos nós, os seus colegas. Após indicar um homem para a cadeira de filosofia da ciência e observá-lo ter sucesso nesse campo por alguns anos, ninguém gosta de descobrir que, de repente, ele volta o seu interesse para o tipo mais heterodoxo de psicanálise, visto que o que estava sendo psicanalisado não era nem mesmo uma pessoa, mas um elemento.

Seguiram-se novos volumes nesse caminho durante os anos seguintes: L'Eau et les Rêves (1942), L'Air et les Songes (1943), La Terre et les Rêveries de la Volonté (1948a), La Terre et les Rêveries du Repos (1948b), nos quais Bachelard guinou resolutamente do universo da razão e da ciência ao da imaginação e da poesia. Tudo nessas obras era novo; eu estava convencido de que o mais importante ainda não estava completamente realizado - e talvez nunca viria a estar, pois o que Bachelard chama de "imaginação" é o poder mais secreto que é tanto uma força cósmica quanto uma faculdade psicológica. Na introdução de L'Eau et les Rêves, resvalando sem pudor em uma das mais antigas categorias filosóficas - e eu acho que poderia dizer por que ele precisou fazer isso - Bachelard distinguiu entre dois tipos de imaginação: a imaginação formal e a imaginação material. O ponto central é que ele encontrou ambas em ação tanto na natureza quanto na mente. Na natureza, a imaginação formal cria toda a beleza desnecessária, como a das flores; a imaginação material, ao contrário, visa a produzir o que, no ser, é simultaneamente primitivo e eterno. Na mente, a imaginação formal é atraída pelo novo, pictórico, variado e inesperado nos eventos, enquanto a imaginação material procura 
pelos elementos de permanência nas coisas. Em nós, como na natureza, a imaginação material é produtora de germes, mas de germes em que a forma é profundamente mergulhada numa substância. As imagens da imaginação formal — isto é, as imagens das formas livres — sempre receberam dos filósofos a devida atenção, mas Bachelard sabia estar realizando um trabalho pioneiro ao voltar-se para as "imagens da matéria" (1942, p. 7). É claro que mesmo essas imagens implicam um elemento formal, mas essas imagens diretas da matéria, como as nomeia, são precisamente as imagens das formas dadas na matéria, e inseparáveis dela. Bachelard tinha consciência de que, ao chamar a atenção dos filósofos para a importância da imaginação material, estava definindo um novo conceito "necessariamente requerido para um estudo filosófico completo da criação poética” (1942, p. 7). Em outras palavras, Bachelard estava se voltando da filosofia da ciência para a filosofia da arte e à estética.

Essa mudança não podia ser realizada senão com um cuidado extremo, especialmente por parte de um filósofo interessado, por tantos anos, nos intrincados, porém precisos, movimentos da mentalidade científica. Desde o início, como podemos ver nas primeiras linhas desta obra (1964), Bachelard percebeu que, se quisesse abordar proveitosamente os problemas sugeridos pela imaginação poética, precisaria esquecer todo o seu conhecimento prévio e todos os hábitos filosóficos contraídos durante anos de reflexão científica. Para mim, pelo menos, o primeiro parágrafo da introdução deste volume é uma das maiores contribuições à filosofia da arte, especialmente à sua metodologia: ele inaugura uma nova era. Ao dissociar cuidadosamente o princípio de uma interpretação correta da arte em relação ao princípio que, corretamente, sempre presidiu esse conhecimento, Bachelard fez todo o possível para estabelecer a especificidade da filosofia da arte na família geral das disciplinas filosóficas.

Cada leitor atento precisará descobrir, por si mesmo, como isso foi feito. Os comentários geralmente são mais extensos que os livros comentados e, em última análise, muito menos claros. Eu somente queria ressaltar a brilhante originalidade de um homem enraizado tão profundamente no solo da vida do dia a dia, e em uma relação tão íntima com as realidades concretas da natureza, que, após investigar cuidadosamente os métodos pelos quais o ser humano alcança a cognição científica, sentiu uma necessidade irresistível de se comunicar com as forças que criam esses métodos. O único campo em que ele poderia ter esperança de observar essas forças em jogo era o poético. Daí a série de escritos em que Bachelard aplicou os princípios do seu novo método - que, neste livro, foram levados à perfeição.

Étienne Gilson

Agosto de 1963 


\section{REFERÊNCIAS}

BACHELARD, G. L'Expérience de l'Espace dans la Physique Contemporaine. Félix Alcan, 1937.

BACHELARD, G. La Psychanalyse du Feu. Paris: Gallimard, 1938.

BACHELARD, G. L'Eau et les Rêves: essai sur l'imagination de la matière. Paris: José Corti, 1942.

BACHELARD, G. L'Air et les Songes: essai sur l'imagination du mouvement. Paris: José Corti, 1943.

BACHELARD, G. La Terre et les Rêveries de la Volonté. Paris: José Corti, 1948a.

BACHELARD, G. La Terre et les Rêveries du Repos. Paris: José Corti, 1948b.

BACHELARD, G. La Poétique de l'Espace. Paris: Presses Universitaires de France, 1957. (Bibliothèque de Philosophie Contemporaine).

BACHELARD, G. The Poetics of Space. Translated from the French by Maria Jolas. Foreword by Etienne Gilson. Boston: Beacon Press, 1964. 